\title{
Nesting and at-sea distribution of marine turtles in Angola, West Africa, 2000-2006: occurrence, threats and conservation implications
}

\author{
Caroline R. Weir, Tamar Ron, Miguel Morais and Agostinho Domingos C. Duarte
}

\begin{abstract}
The status of marine turtles in Angola, West Africa, is poorly known, and therefore during 2000-2006 a combination of both dedicated and opportunistic beach and at-sea turtle surveys were carried out, and interviews conducted with fishing communities and at markets. Green Chelonia mydas, olive ridley Lepidochelys olivacea, leatherback Dermochelys coriacea and loggerhead turtles Caretta caretta were recorded, and nesting of the first three species confirmed during SeptemberMarch (peaking November-December). Green turtles nested mainly in the south, leatherback turtles in north and central Angola, and olive ridley turtle nesting was widespread. Olive ridley turtle nest density at
\end{abstract}

Palmeirinhas averaged 32 nests $\mathrm{km}^{-1}$. At-sea surveys produced 298 turtle records, with peak occurrence during August. Significant anthropogenic-related mortality (including exploitation of meat and eggs and fishing bycatch) was recorded, in addition to natural predation and other threats. Maintenance of the longterm sustainability of these turtle populations should focus on the involvement of fishing communities and increasing awareness throughout Angola.

Keywords Angola, exploitation, green turtle, leatherback turtle, loggerhead turtle, nesting, olive ridley turtle.

\section{Introduction}

The distribution and status of marine turtles along Angola's 1,650 km coastline is poorly understood. Loggerhead Caretta caretta, green Chelonia mydas, hawksbill Eretmochelys imbricata, olive ridley Lepidochelys olivacea and leatherback turtles Dermochelys coriacea were recorded in the 1960s and 1970s (Brongersma, 1961, 1982; Hughes et al., 1973; Huntley, 1974) and early 1980s (Carr \& Carr, 1991). These studies identified widespread nesting of olive ridley and leatherback turtles, with both species also observed at sea in coastal areas (Carr \& Carr, 1991). Green turtles are known to nest (Monard, 1937), and Mussulo Bay and Foz de Cunene may provide yearround feeding habitat for all age classes of this species (Carr \& Carr, 1991; Fretey, 2001). Although hawksbill turtles have been occasionally reported in Angola, there are no confirmed instances of nesting (Hughes et al., 1973; Carr \& Carr, 1991). The status of loggerhead turtles is also

Caroline R. Weir (Corresponding author) Ketos Ecology, 4 Compton Road, West Charleton, Kingsbridge, Devon, TQ7 2BP, UK.

E-mail caroline.weir@ketosecology.co.uk

Tamar Ron 27 Ramban Street, Jerusalem 92422, Israel.

Miguel Morais University of Agostinho Neto, Faculdade de Ciências, Av. 4 de Fevereiro, $N^{\circ} 71,4$ ad, sala 4.23, Luanda, Angola.

Agostinho Domingos C. Duarte Instituto de Desenvolvimento da Pesca Artesanal, Rua José Tuca, Cx. Postal 83, Luanda, Angola.

Received 1 August 2006. Revision requested 6 November 2006. Accepted 7 January 2007 unclear, and surveys have not detected the species at nest sites or in coastal waters (Carr \& Carr, 1991).

All turtle species occurring in Angola are categorized globally as Endangered (green, olive ridley and loggerhead) or Critically Endangered (leatherback and hawksbill) on the IUCN Red List (IUCN, 2006). In November 1972 the Angolan Regulamento de Caça prohibited harming turtles and their eggs or nests (Huntley, 1974), although this law is poorly enforced (Carr \& Carr, 1991). Turtles are also protected under Angola's Aquatic Resources Law, and are a priority species for the National Strategy for Biodiversity. The Angolan government signed the Abidjan Memorandum (CMS, 1999) in 2002, which requires conservation of marine turtles within West Africa. Some nesting populations exist within protected areas, including national parks, reserves and private beaches. However, adult turtles are killed for their meat (Hughes et al., 1973; Ron, 2002) and large numbers of eggs are harvested annually (Hughes et al., 1973; Hughes, 1982; Carr \& Carr, 1991; Morais, 2004), even within protected areas. A variety of wild carnivores and domestic animals, including dogs and pigs (Carr \& Carr, 1991), also predate eggs. Turtles taken as accidental bycatch in fishing gear (including gill nets, hand lines and beach seine nets) are often consumed (Carr \& Carr, 1991).

Here we present updated information on the nesting and at-sea distribution of marine turtles in Angola and assess the conservation implications for the country's turtle populations. 


\section{Study area}

Angola is located on the west coast of Africa in the south-east Atlantic Ocean (Fig. 1); it includes Cabinda, a small exclave located between Congo and the Democratic Republic of Congo (DRC). Most of Angola's coastal fringe consists of narrow dynamic sandy beaches (Huntley, 1974). The continental shelf ( $<200 \mathrm{~m}$ depth) extends to $c .50 \mathrm{~km}$ from the coast but is narrower $(<10 \mathrm{~km})$ west of Luanda and south of Lobito. Water depth increases to $>5,000 \mathrm{~m}$ in the Angola Basin. The oceanography off Angola is dominated by the warm water, southward-flowing Angola Current and the cold water, nutrient rich, northward-flowing Benguela Current, which converge at $17-13^{\circ} \mathrm{S}$ (depending on season) at the Angola-Benguela Front (Moroshkin et al., 1970).

\section{Methods}

A nesting survey was conducted on a protected beach at Palmeirinhas (Fig. 1) during: (1) 15 November 2003 to 15 March 2004 (5 km monitored), (2) 15 September

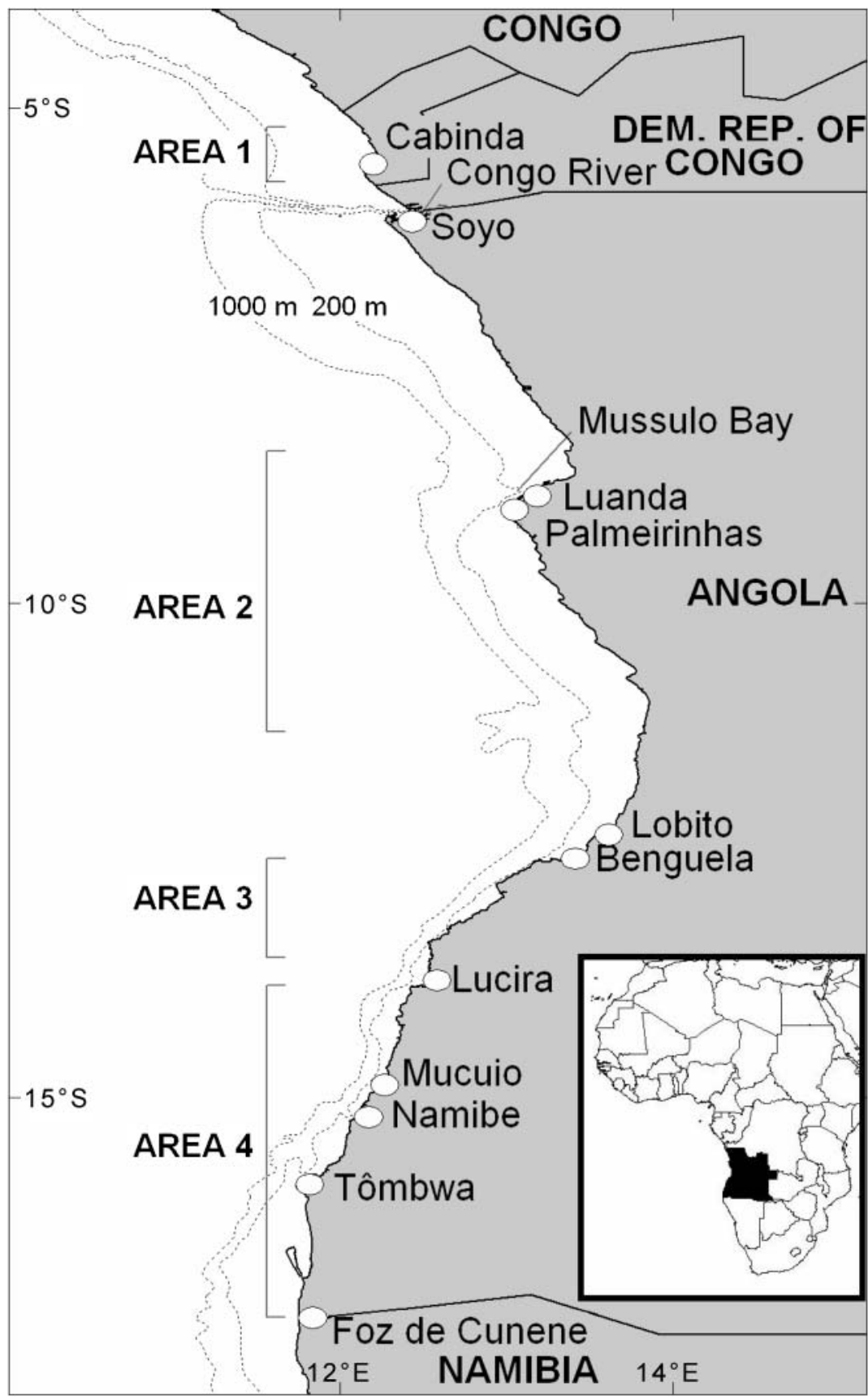

Fig. 1 Location of the study area on the coast of Angola, with the four geographic areas indicated. The inset indicates the location of Angola in Africa. 
2004 to 31 March 2005 (3.5 km monitored), and (3) 15 September 2005 to 31 March 2006 (3.5 km monitored). Trained personnel surveyed the beach weekly to collect data on curved carapace length (CCL) and width (CCW; Pritchard et al., 1983) and clutch size (using direct counts and excavation of unhatched nests), to apply tags (FAO Monel tags), and record natural and anthropogenic predation. Trained local people carried out daily surveys to locate and identify crawls. The data were analysed to examine variation in turtle nesting density.

To assess turtle nesting elsewhere, opportunistic surveys were conducted at selected beaches in four areas during 2000-2003: (1) Cabinda Province, (2) Bengo, Luanda and Cuanza Sul Provinces, (3) Benguela Province, and (4) Namibe Province (Fig. 1). Trained personnel surveyed 2-20 km stretches of beach at night or in the day (collecting data on nest signs, hatchlings and mortality), and local fishermen were interviewed to acquire additional information. Surveys were carried out as opportunity arose and were not quantitative in nature. During 2000-2001 the surveys were concentrated in Areas 1 and 2, and Areas 3 and 4 were only surveyed during December 2002 (Fig. 1; Table 1).

During August 2004-May 2005 offshore data on marine turtles were collected from two geophysical seismic survey vessels travelling at speeds of 4-7 knots. Effort logs (position, time, water depth and environmental data) and sighting data (species, behaviour, position, water depth, and distance from the ship) were kept. The relative abundance (number of turtles per 100 minutes of effort) was compared between months using only data collected in Beaufort sea states $\leqslant 2$ to ensure a reasonable level of detection.

Anthropogenic-related turtle mortality was examined using interviews with fishermen and observations of carcasses during the beach surveys. Additional data were collected in a market survey in Benguela and from interviews with Namibe long-line fishermen. Enquiries at Benguela revealed that turtle eggs found on the market were collected at Baia do Cuio $(60 \mathrm{~km}$ west of Benguela), and this region was visited in March 2006 to examine any potential impacts. During January 2005
Namibe, Tômbwa and Mucuio were visited to assess turtle bycatch in local artisanal long-line fisheries, which target sea birds using 20-50 m lines containing 30-70 hooks.

\section{Results}

\section{Palmeirinhas}

Although one green turtle carcass was observed, only leatherback and olive ridley turtles were recorded nesting at Palmeirinhas. The nesting and biometric parameters of both species are provided in Table 2. Olive ridley turtles had higher annual nest count and density than leatherback turtles. Nesting typically commenced during early October and continued until February (Fig. 2; Table 2). No tagged turtles were recaptured at Palmeirinhas. The period between laying and emergence of hatchlings was c. 50 and 60 days for olive ridley and leatherback turtles, respectively. About $52 \%$ of nests experienced natural predation, primarily from side-striped jackal Cannis adustus but also from spotted genet Genetta tigrina, African wild cat Felis libica, serval Felis serval, fiddler crabs Uca tangeri, monitor lizards Varanus sp. and birds (e.g. palm-nut vulture Gypohierax angolensis). Beach erosion and flooding destroyed a further $23 \%$ of nests.

\section{Coastline assessment}

Three turtle species were found nesting on Angolan beaches (Table 1). Olive ridley and leatherback turtles were the most frequently encountered species, with nests, carcasses and carapaces recorded in central and northern areas, and as far south as Benguela Province. Green turtle activity occurred predominantly within Namibe Province in the south, with unconfirmed reports from Cabinda. Heavy egg predation by blackbacked jackals Canis mesomelas was recorded in Namibe Province. Fishermen reported juvenile green turtles year-round off Foz de Cunene, Mussulo Bay, Tômbwa and Cabinda. There were unconfirmed reports from fishermen of loggerhead turtle nesting in Cabinda and

Table 1 Records of nesting turtles, carcasses and bycatch during opportunistic beach surveys carried out along the coast of Angola, 20002003.

\begin{tabular}{|c|c|c|c|c|c|}
\hline Region (Fig. 1) & Survey months & Total survey days & Nesting species (rare) & Carcasses & Bycatch \\
\hline 1 & Oct.-Nov., Jan.-Feb. & 11 & $\begin{array}{l}\text { Leatherback, olive ridley, } \\
\text { (green) }\end{array}$ & $\begin{array}{l}\text { Leatherback, olive } \\
\text { ridley }\end{array}$ & Green, olive ridley \\
\hline 2 & Oct.-Feb. & 9 & $\begin{array}{l}\text { Leatherback, olive ridley, } \\
\text { (green) }\end{array}$ & $\begin{array}{l}\text { Green, leatherback, } \\
\text { olive ridley }\end{array}$ & Green, olive ridley \\
\hline 3 & Dec. & 2 & Leatherback, olive ridley & Olive ridley & \\
\hline 4 & Dec. & 6 & Green, olive ridley & Green & \\
\hline
\end{tabular}


Table 2 Nesting and biometric data for olive ridley and leatherback turtles at Palmeirinhas, 2003-2006.

\begin{tabular}{|c|c|c|c|c|}
\hline & \multicolumn{3}{|c|}{ Nesting season } & \multirow[b]{2}{*}{ Mean } \\
\hline & $2003 / 04^{1}$ & $2004 / 05$ & $2005 / 06$ & \\
\hline \multicolumn{5}{|l|}{ Olive ridley turtle } \\
\hline Total nest count & 105 & 143 & 120 & 122.7 \\
\hline Nest density $\left(\mathrm{km}^{-1}\right)$ & 21 & 40.86 & 34.29 & 32.05 \\
\hline Date first nest recorded ${ }^{1}$ & 15 Nov. $^{1}$ & 7 Oct. & 15 Oct. & \\
\hline Date last nest recorded & 2 Feb. & 28 Jan. & 12 Jan. & \\
\hline $\begin{array}{l}\text { Nesting season duration } \\
\text { (days) }\end{array}$ & $79^{1}$ & 112 & 89 & \\
\hline Curved carapace length (c & & & & 71.5 \\
\hline Curved carapace width (c & & & & 71.5 \\
\hline Clutch size & & & & 122 \\
\hline \multicolumn{5}{|l|}{ Leatherback turtle } \\
\hline Total nest count & 27 & 9 & 4 & 13.3 \\
\hline Nest density $\left(\mathrm{km}^{-1}\right)$ & 5.40 & 2.57 & 1.14 & 3.04 \\
\hline Date first nest recorded ${ }^{1}$ & 17 Nov. $^{1}$ & 6 Nov. & 12 Oct. & \\
\hline Date last nest recorded & 1 Feb. & 26 Jan. & 11 Feb. & \\
\hline $\begin{array}{l}\text { Nesting season duration } \\
\text { (days) }\end{array}$ & $74^{1}$ & 81 & 132 & \\
\hline \multicolumn{4}{|c|}{ Curved carapace length $(\mathrm{cm})$} & 149.7 \\
\hline \multicolumn{4}{|c|}{ Curved carapace width $(\mathrm{cm})$} & 89.8 \\
\hline \multicolumn{4}{|l|}{ Clutch size } & $90^{2}$ \\
\hline
\end{tabular}

${ }^{1}$ No data were collected during September and October 2003 ${ }^{2}$ Includes c. $25 \%$ of infertile eggs

hawksbill turtle nesting at several beaches from Cabinda to Namibe. Interviews revealed that the nesting season in Benguela Province northwards commences after the first rain (September-November), peaks in NovemberDecember, and continues at low density until February, with hatching following 2 months later. Nesting in Namibe Province starts later, in mid December, peaks in January, and continues into March.

\section{At-sea surveys}

A total of 3,268 h of at-sea data was collected, mainly over depths of 1,500-2,499 m. Olive ridley (65 sightings, 73 individuals, 0.72 turtles per 100 minutes effort), green $(n=1)$, loggerhead ( $n=12,0.08$ turtles per 100 minutes effort) and leatherback $(n=4)$ turtles were recorded in a

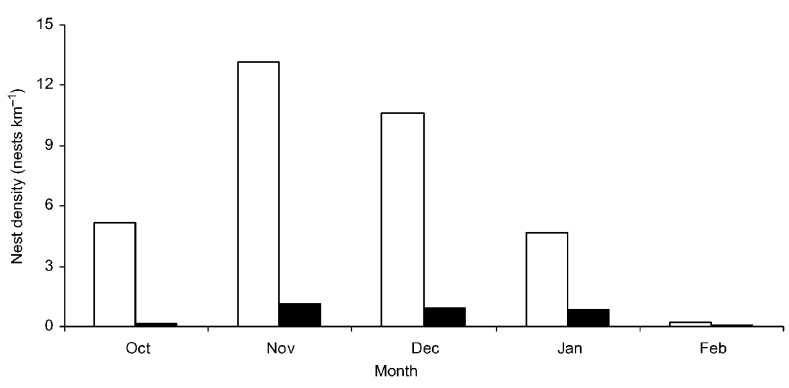

Fig. 2 Seasonality in nesting density of olive ridley (white) and leatherback (black) turtles at Palmeirinhas, 2003-2006. total of 298 sightings. Basking of turtles at the surface during calm weather increased the probability of their detection: $84 \%$ of turtles were recorded in Beaufort sea state $\leqslant 2$, despite these sea states comprising only $26 \%$ $(842 \mathrm{~h})$ of total effort. A peak in turtle numbers and relative abundance occurred during August (but note there was no survey effort in June or July; Fig. 3). Positive identification was restricted to animals within $400 \mathrm{~m}$ of the vessel (within $600 \mathrm{~m}$ for leatherback turtles), and $72 \%(n=216)$ of turtles were unidentified, although all were hard shelled species (Fig. 4A).

Sightings of olive ridley turtles were most numerous north-west of Luanda and west of the Congo River (Fig. 4B). Offshore density was lowest during December-May and highest in August-September. Nine mating pairs were recorded between 31 August and the end of September. All sightings of loggerhead turtles occurred over deep water (1,343-2,783 m; Fig. 4C) during August-November, with seven recorded during a 12-day period in September 2005. Leatherback turtles were recorded over 1,908-2,009 $\mathrm{m}$ depths during January-February (Fig. 4C), with a single animal $9 \mathrm{~km}$ off the Congo River mouth during September. The single green turtle was recorded over shelf waters $(81 \mathrm{~m}$ depth) off Soyo during August (Fig. 4C).

\section{Conservation assessment}

Interviews with fishing communities revealed widespread turtle exploitation, with both meat and eggs used for local subsistence. Exploitation has increased since the early 1990s due to increased poverty levels and human habitation in coastal areas resulting from the influx of internally displaced people escaping conflict. The Angolan Civil War began following independence from Portugal in 1974, and only formally ended in 2002. The war greatly intensified during the 1980s and 1990s, resulting in coastal settlements of people reliant on natural resources for subsistence. Commercial poaching also occurs adjacent to the heavily populated areas of Cabinda, Luanda and Benguela, resulting in 100\% use

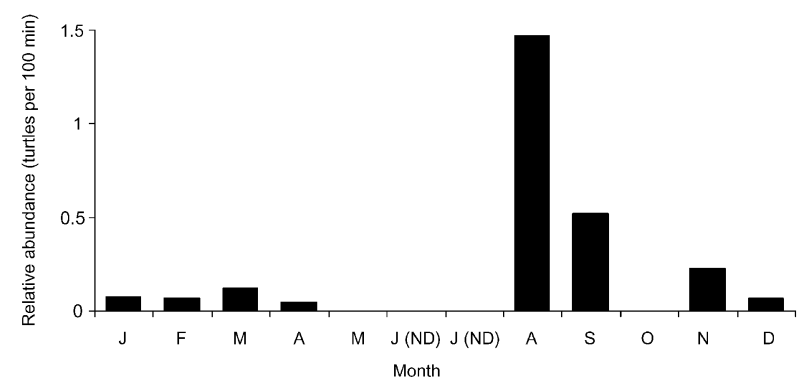

Fig. 3 Relative monthly abundance of marine turtles (all species combined) at-sea off Angola. ND, no survey data. 

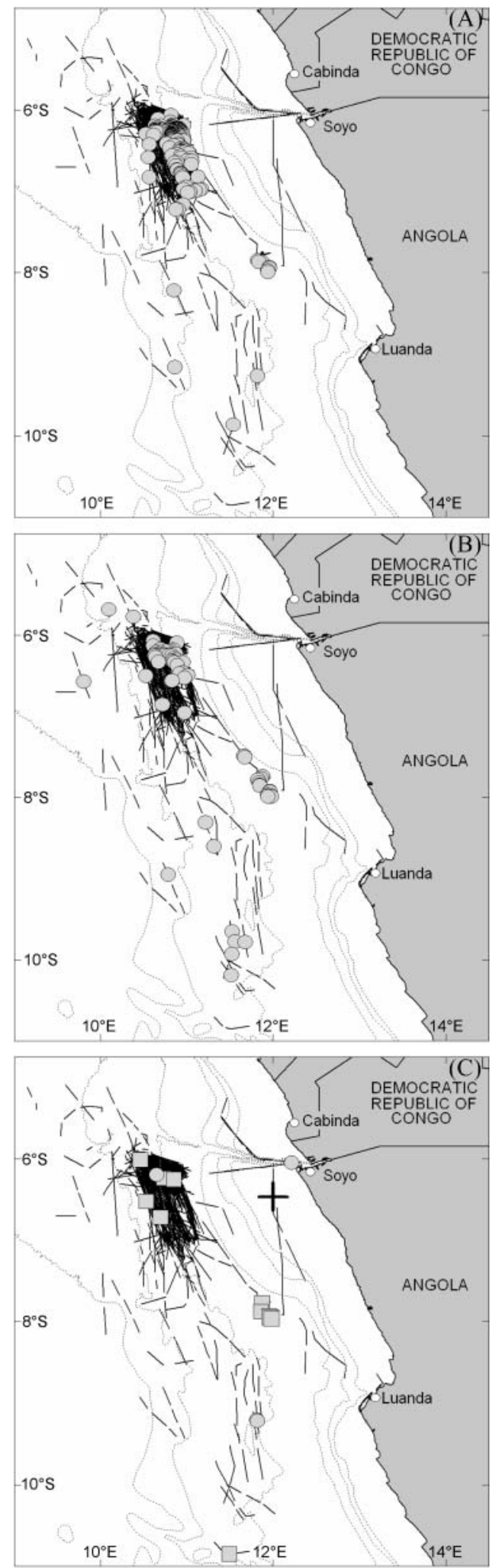

Fig. 4 Location of at-sea turtle sightings off Angola: (A) unidentified hard shell turtles $(n=216)$; (B) olive ridley turtles $(n=65)$; $(C)$ green $(\mathrm{n}=1$; cross symbol), loggerhead $(\mathrm{n}=12$; square symbol) and leatherback ( $\mathrm{n}=4$; circle symbol) turtles. Survey effort is shown in black. Bathymetry: 200, 500, 1,000, 2,000, 3,000 and 4,000 m. of turtle meat, carapaces and eggs on some beaches. Human habitation, and consequently turtle use, is scarcer in Namibe Province. However, large-scale hunting of juvenile green turtles for meat was reported in Foz de Cunene. Interviews revealed that egg collection at Baia do Cuio destined for the Benguela market occurred only once per week, with 1-3 olive ridley turtle nests located daily.

Accidental bycatch of turtles in artisanal fishing gear was widespread. Sporadic green turtle bycatch was reported and occurs year-round in Cabinda Province. Most of the 48 turtle carcasses (adults of both sexes) recorded at Palmeirinhas showed evidence of bycatch such as net marks. In Namibe Province interviewees identified several nesting areas that coincided with long line fishing areas. However, bycatch of turtles (reported to comprise olive ridley, leatherback, loggerhead and hawksbill turtles) in this fishery is relatively small (though occurring year-round) at 2-3 animals per month. Most are killed for local use of their meat, although some are used commercially (carapaces and oil). At Mucuio the fishermen care for wounded turtles in tanks and later return them to sea.

Turtle bycatch also occurs offshore in discarded commercial fishing gear. At-sea observations included several olive ridley turtles entangled in coarse netting and a leatherback turtle caught in submerged monofilament netting. Other identified threats to nesting turtles include habitat loss due to sand extraction for building, nest predation by domestic dogs and natural predators, natural beach erosion, crushing of nests by vehicles, flooding during high tides and nests destroyed by plant growth.

\section{Discussion}

\section{Turtle species in Angola}

Our findings agree with Hughes et al. (1973), Huntley (1974), Carr \& Carr (1991) and Fretey (2001), in recording olive ridley, leatherback, green and loggerhead turtles in Angola. Although Hughes et al. (1973) and Huntley (1974) additionally report hawksbill turtles, we did not observe this species. As previously noted (Hughes et al., 1973; Carr \& Carr, 1983; A.L. Guerra Marques, pers. comm.) olive ridley turtles are the most abundant and widespread species in Angola. However, this species is declining worldwide and is a priority for conservation in West Africa (Fretey, 2001).

Leatherback turtle occurrence was similar to that reported by Hughes et al. (1973) and Carr \& Carr (1991), nesting primarily in warmer northern regions with little activity south of Benguela. Their distribution is probably a continuum of the major Gabon nesting population 
(Fretey, 2001), where 6,000-7,000 females breed annually on a single $90 \mathrm{~km}$ stretch of coast (Billes et al., 2006). Since turtles nest in 2-3 year cycles, the recorded decrease in nest density at Palmeirinhas over the 3-year monitoring period may represent a natural abundance cycle or a change in nesting conditions or site use, rather than necessarily a decrease in the population.

Most green turtle nesting occurred in Namibe Province. However, in contrast to previous data (Hughes et al., 1973; Huntley, 1974; Hughes, 1982; Carr \& Carr, 1991), our data indicate little (and unconfirmed) nesting in central and northern Angola and none at Palmeirinhas, a documented nest site in the 1980s (Carr \& Carr, 1991). It is unclear whether this change represents a decline in the population or altered nesting distribution. The year-round concentrations of adults and juveniles previously reported at Mussulo Bay and Foz de Cunene (Carr \& Carr, 1991) are still reported by fishermen, and together with the Tômbwa foraging site, should be protected to ensure long-term conservation of important habitat.

The status of loggerhead turtles in Angola remains unclear, with no confirmed evidence of nesting, although the species was recorded offshore and as coastal bycatch. A proliferation of at-sea sightings during September 2005, in addition to reports from fishermen and bycatch of this species in Cabinda during 2004-2005, may indicate spatio-temporal variation in their occurrence off Angola. Loggerhead turtles move great distances through deep-water habitat in West Africa (Hawkes et al., 2006) and animals observed off Angola might represent a non-nesting foraging population.

\section{Distribution and seasonal occurrence}

Marine turtles occupy various habitats in Angola, including nesting beaches, and coastal, neritic, shelfedge and oceanic waters. As noted by Carr \& Carr (1991) nesting occurs primarily between October and February and the onset apparently coincides annually with the start of the rainy season. Climatic influences from the Benguela Current result in a shorter rainy season, and colder and more variable air and water temperatures in southern Angola (Huntley, 1974) that may result in later onset of nesting (Solow et al., 2002; Weischampel et al., 2004). Nesting commencement and duration may therefore vary during the Benguela Niño, when weak southerly winds limit the northward extent of the Benguela Current, producing warmer water temperatures and potentially extending the nesting season in southern Angola.

Our data indicated widespread year-round occurrence of turtles in oceanic areas. Their distribution may vary in response to productivity (Polovina et al., 2004) and changes in the direction and speed of oceanic currents (Polovina et al., 2004; Hawkes et al., 2006), in addition to the inshore-offshore movements related to the nesting season.

In coastal waters turtle density peaks during the breeding season, with lower densities during AprilSeptember (Carr \& Carr, 1991). During 2004 and 2005 (when at-sea and nesting surveys occurred simultaneously) peak density of olive ridley turtles in offshore waters occurred during August-September and nesting started at Palmeirinhas at the beginning of October. Although Palmeirinhas is located south of the at-sea survey area, it appears that turtles aggregated c. $100 \mathrm{~km}$ offshore 4-8 weeks prior to nesting. The nine at-sea observations of mating olive ridley turtles occurred primarily during September, also indicating seasonality in reproductive behaviour.

\section{Conservation issues}

Direct harvest of eggs and meat and fisheries bycatch have been major causes of anthropogenic-related turtle mortality in Angola since the 1970s (Hughes et al., 1973; Carr \& Carr, 1983). However, both have intensified in relation to increasing coastal human habitation and rising poverty, particularly since the settlement in the 1980s and 1990s of internally displaced people reliant on natural resources for subsistence. Although limited exploitation of turtles by stable coastal communities is potentially sustainable, the situation escalates when large numbers of additional people are displaced into coastal areas (Brongersma, 1982). Natural predation and beach erosion also destroy nests, and mitigation measures based on fences and netted hatcheries could be considered in the future where these impacts are significant. Habitat destruction through sand extraction is likely to increase with growing urban development and the rebuilding of infrastructure in Angola's postconflict rehabilitation.

Some success has been achieved in addressing exploitation via national legislation, extensive awareness campaigns since 2000, and localized efforts such as fines in Benguela, and incentives to release live turtles caught in fishing nets in Cabinda (Tamar Ron, pers. obs.). Since exploitation occurs both locally and commercially, a combined approach is required to maximize law enforcement (focusing on professional hunters) and involve coastal communities in conservation and development of alternative livelihoods. Addressing the threats from non-intentional bycatch is more problematic. Evidence of bycatch is widespread, particularly within coastal artisanal fishing gear (gill nets, beach seine nets and long-lines) deployed adjacent to nesting 
beaches. Mitigation of this bycatch could be achieved via restrictions in the deployment of fishing nets during the nesting season (Pandav et al., 1997). However, alternate sources of income would be needed for coastal communities to implement such measures successfully. Significant turtle mortality probably also occurs during commercial fishing operations (including trawling, purse seine and long-line fisheries; Hillestad et al., 1982; Pandav et al., 1997). The potential impact of offshore industrial activities and oil spills on Angola's nesting and foraging marine turtle populations are presently unknown and require study.

Conservation of marine turtles in Angola must take into account the use by local people of turtles as a food source (Hughes, 1982). Considering the numerous impoverished coastal communities, the presence of internally displaced people, the absence of accurate population and life cycle data for turtles, the fact that turtles comprise only a seasonal subsistence source, and the absence of efficient enforcement systems, controlled exploitation of turtles is not currently a practical solution. A better approach may be to provide alternative protein and income sources via alternative sustainable livelihoods or sustainable forms of husbandry. Ecotourism could provide alternative future income for some coastal communities. The management and protection of turtle populations in Angola will need to be carried out in consultation with the relevant coastal fishing communities and their traditional leadership.

\section{Acknowledgements}

We are grateful to MINUA, MINP, UNDP, NORAD, CABGOC, JEA, Gremio ABC, Provincial Government of Cabinda, ANU, National Natural History Museum, TPA, Orion, NRA, Journal de Angola, Provincial delegations of Kwanza Sul, Benguela and Namibe. TR thanks Miguel Kassessa, Joao Vintem, Joao Christo, Esteves Afonso, Simao Zau, Alfredo Buza, Luis Encoge, Martins Pinto, Abias Huongo, Martin Davies, Agostinho Chicaia, Marcos Nhunga, Antonio Grillo, Catchi Lucas, Rico Sacco, Alvaro Baptista and Adelino Nunes. MM is grateful to the proprietors of Praia da Onça Farm for their support, the biology students of UAN-FC and associates of the NAFC for fieldwork assistance, and those bodies that sponsored the Palmeirinhas fieldwork. AD thanks Tomas Rosa Flor (Benguela IPA representative), and Luzia Augusto, Joana Pinheiro and Alice Martins (Namibe IPA representatives). CW is grateful to Nathan Gricks for collecting data, and the crews of the Geco Triton and the Sea Trident for their hospitality. BP Angola and their partners in Blocks 18 and 31 sponsored the at-sea survey work.

\section{References}

Billes, A., Fretey, J., Verhage, B., Huijbregts, B., Giffoni, B., Prosdocimi, L., Albareda, D.A., Georges, J-Y. \& Tiwari, M. (2006) First evidence of leatherback movement from Africa to South America. Marine Turtle Newsletter, 111, 13-14.

Brongersma, L.D. (1961) Notes upon some sea turtles. Zoologische Verhandelingen Rijksmuseum van Natuurlijke Historie te Leiden, 51, 1-46.

Brongersma, L.D. (1982) Marine turtles of the Eastern Atlantic. In Biology and Conservation of Sea Turtles (ed. K. Bjorndal), pp. 407-416. Smithsonian Institution Press, Washington, DC, USA.

Carr, T. \& Carr, N. (1983) Survey of the Sea Turtles of Angola. Unpublished report to the New York Zoological Society, New York, USA.

Carr, T. \& Carr, N. (1991) Surveys of the sea turtles of Angola. Biological Conservation, 58, 19-29.

CMS (Convention on Migratory Species) (1999) Memorandum of Understanding Concerning Conservation Measures for Marine Turtles of the Atlantic Coast of Africa. Agreement under Convention on the Conservation of Migratory Species of Wild Animals, Abidjan, Ivory Coast.

Fretey, J. (2001) Biogeography and Conservation of Marine Turtles of the Atlantic Coast of Africa/ Biogéographie et conservation des tortues marines de la côte atlantique de l'Afrique. CMS Technical Series Publication No. 6, UNEP/CMS Secretariat, Bonn, Germany.

Hawkes, L.A., Broderick, A.C., Coyne, M.S., Godfrey, M.H., Lopez-Jurado, L-F., Lopez-Suarez, P., Merino, S.E., Varo-Cruz, N. \& Godley, B.J. (2006) Phenotypically linked dichotomy in sea turtle foraging requires multiple conservation approaches. Current Biology, 16, 990-995.

Hillestad, H.O., Richardson, J.I., Mcvea, Jr, C. \& Watson, Jr, J.M. (1982) World wide incidental capture of sea turtles. In Biology and Conservation of Sea Turtles (ed. K. Bjorndal), pp. 489-495. Smithsonian Institution Press, Washington, DC, USA.

Hughes, G.R. (1982) Conservation of sea turtles in the Southern African region. In Biology and Conservation of Sea Turtles (ed. K. Bjorndal), pp. 397-404. Smithsonian Institution Press, Washington, DC, USA

Hughes, G.R., Huntley, B. \& Wearne, D. (1973) Conservation around the world: sea turtles in Angola. Biological Conservation, 5, 58-59.

Huntley, B.J. (1974) Outlines of wildlife conservation in Angola. Journal of South African Wildlife Management and Assessment, 4, $157-166$.

IUCN (2006) 2006 IUCN Red List of Threatened Species. IUCN, Gland, Switzerland [http://www.redlist.org, accessed 18 May 2006].

MINUA (Ministry of Urban Affairs and Environment) (2006) Estratégia e Plano de Acção Nacionais para a Biodiversidade NBSAP. Documento para discussão, Luanda, Angola.

Monard, A. (1937) Contribution à l'herpétologie d'Angola. Arquivos do Museu Bocage, 8, 19-153.

Morais, M.V. (2004) Avaliação do status das tartarugas marinhas entre os kms 54 e 64 da estrada da Barra do Cuanza. Faculdade de Ciências, Dei Biologia, Luanda, Angola.

Moroshkin, K.V., Bunov, V.A. \& Bulatov, R.P. (1970) Water circulation in the eastern South Atlantic Ocean. Oceanology, 10, 27-34.

Pandav, B., Choudhury, B.C. \& Kar, C.S. (1997) Mortality of olive ridley turtles Lepidochelys olivacea due to incidental capture in fishing nets along the Orissa coast, India. Oryx, 31, 32-36. 
Polovina, J.J., Balazs, G.H., Howell, E.A., Parker, D.M., Seki, M.P. \& Dutton, P.H. (2004) Forage and migration habitat of loggerhead (Caretta caretta) and olive ridley (Lepidochelys olivacea) sea turtles in the central North Pacific Ocean. Fisheries Oceanography, 13, 36-51.

Pritchard, P.C.H., Bacon, P., Berry, F.H., Carr, A., Fletmeyer, J., Gallagher, R.M., Hopkins, S., Lankford, R., Marquez, M.R., Ogren, L.H., Pringle, Jr, W., Reichart, H. \& Witham, R. (1983) Manual of Sea Turtle Research and Conservation Techniques, 2nd Edition (eds K.A. Bjorndal \& G.H. Balazs). Center for Environmental Education, Washington, DC, USA.

Ron, T. (2002) Preliminary Marine Turtle Survey along the Coastline of Angola - A Periodic Report, October-December, 2002. Unpublished report to UNDP-Angola and the Ministry of Urban Affairs and Environment of Angola, Luanda, Angola.

Solow, A.R., Bjorndal, K.A. \& Bolten, A.B. (2002) Annual variation in nesting numbers of marine turtles: the effect of sea surface temperature on re-migration intervals. Ecology Letters, 5, 742-746.

Weishampel, J.F., Bagley, D.A. \& Ehrhart, L.M. (2004) Earlier nesting by loggerhead sea turtles following sea surface warming. Global Change Biology, 10, 1424-1427.

\section{Biographical sketches}

Caroline Weir's research interests focus on the cetaceans and marine turtles off Angola, where she has conducted offshore field research and consultancy work since early 2004.

Tamar Ron was UNDP Biodiversity Chief Technical Adviser for the Government of Angola during 2000-2004, during which she carried out turtle survey work and awareness campaigns as part of a conservation capacity-building initiative in Angola.

Miguel Morais' interests include aquatic mammals, turtles and sea birds in Angola. He provides advice to national and international institutions, and has led a conservation research project on Angola's sea turtles since 2003.

Agostinho D.C. Duarte is General Director of the Institute of Development for the Artisanal Fisheries and Aquaculture of Angola, which works with fishing communities. He previously carried out research at the Angola Research Marine Institute. 